\title{
Effect of Various Factors on the Brazed Joint Properties in Al Brazing Technology
}

\author{
Ashutosh Sharma*, Seung Hyun Lee**, Hyung Oh Ban**, Young Sik Shin*** \\ and Jae-Pil Jung*, $\dagger$ \\ *Dept. of Materials Science and Engineering, University of Seoul, Seoul 02504, Korea \\ **Hyundai Motor Group, Automotive R \& D Division, Hwaseong 18280, Korea \\ ***S K Brazing Co., Siheung 14946, Korea
}

†Corresponding author : jpjung@uos.ac.kr

(Received January 6, 2016 ; Revised January 28, 2016 ; Accepted February 2, 2016)

\begin{abstract}
Last few decades have seen a rapid increase in the fabrication and characterization of $\mathrm{Al}$ alloys for automobiles, heat exchangers and aerospace industries. Aluminium alloys are popular because of their high specific strength, light weight, excellent wear and high oxidation resistance. The development of aluminium alloys in these applications makes their study and research of utmost importance. Brazing is applied to the aluminium alloys for joining various aluminium parts together in most of the industrial applications. Various parameters affect the joining process of these aluminium alloys. In this article, various types of processing parameters have been discussed, and special attention has been given to the category of aluminium brazing alloys. The article reviews on the various parameters that affect the brazing property in various scientific and technological applications.
\end{abstract}

Key Words : Brazing, Joining, Automotive, Induction, Wettability, Intermetallic.

\section{Introduction}

The brazing refers to the joining process of heating a joint to the liquidus temperature of the used filler metal over $450{ }^{\circ} \mathrm{C}$, and below the solidus temperature of the base material. During this process, the base metals are not affected due to a lower brazing temperature than their melting points ${ }^{1,2)}$. It should be also noted that brazing temperature is always lower than welding temperature. Though brazing is similar to the soldering procedure yet the temperatures involved are even lesser than in brazing process, i.e. $<450{ }^{\circ} \mathrm{C}$. However, the welding temperature of a filler metal may be significantly higher than the melting point of the base material ${ }^{3,4}$. Brazing provides a metallurgical bonding between the contact surfaces and the filler metal without melting the base met$\mathrm{al}^{3-5}$. There are various types of brazing processes such as dip brazing, induction brazing, laser brazing, resistance brazing, furnace brazing, and oxyacetylene flame brazing $^{6-11)}$. A summary of different types of joining processes in metallurgy is described in Fig. 1.
A major advantage of brazing is that we can join dissimilar metals or ceramics with full perfection. There are various examples reported in literature where ceramic to metal joints are successfully brazed and investigated $^{12-15)}$. Direct or active metal brazing has been investigated where an active element like $\mathrm{Ti}$ or $\mathrm{Zr}$ is used in conjunction with the filler metal to wet the contacting surfaces. As a consequence, the need for conducting coating is minimized ${ }^{12)}$.

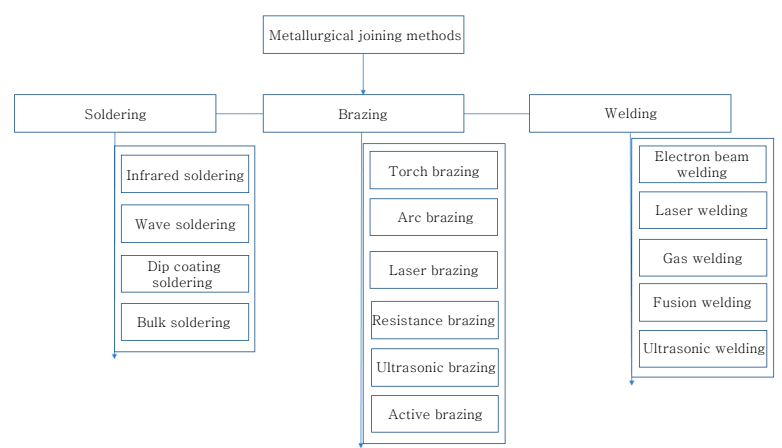

Fig. 1 Different types of metallurgical joining processes 


\section{Experimental steps in brazing}

Brazing process generally composed of a series of steps depending on the joint to be brazed. The surface to be joined should be properly cleaned to avoid any defect in the brazed joint. The number of steps can be as follows:

1. Surface preparation

2. Proper fit and clearance

3. Use of suitable flux (NOCOLOK flux etc.)

4. Fixing the two parts to be joined

5. Heating the parts to the particular brazing temperature

6. Cleaning of the joint to avoid the residues, if any

\section{Brazing parameters}

Brazing parameters play an important role in the brazed joint characteristics. All the brazing joint parameters should be dealt with great care to produce a fruitful joint. Some of the important brazing parameters can be classified as follows:

\subsection{Brazing temperature}

Brazing temperature is the most widely investigated parameter. Temperature has a strong effect on the final brazed strength and the corrosion properties. A high temperature can change the brazed joint morphology and even may cause softening, cracks generation, ultimately leading to the joint failure. For example, in the active metal brazing of $\mathrm{Al}_{2} \mathrm{O}_{3} / \mathrm{Cu}$ joint with $\mathrm{Ag}-\mathrm{Cu}-\mathrm{Zr}-\mathrm{Sn}$ filler, low brazing temperature is usually beneficial to maintain the superior bonding strength ${ }^{16)}$. It is also reported that the interface thickness rises with the increase in temperature of silicon nitride joints using Ag-Cu-Ti -Mo filler metal under vacuum ${ }^{17)}$. Yang et. al. found that different types of reaction products are formed while brazing $\mathrm{Al}_{2} \mathrm{O}_{3} / \mathrm{Ti}-6 \mathrm{Al}-4 \mathrm{~V}$ with $\mathrm{Ag}-\mathrm{Cu}-\mathrm{Ti}-\mathrm{B}$ filler. Different reaction products (i.e., $\mathrm{TiCu}, \mathrm{Ti}(\mathrm{Cu}, \mathrm{Al})$, $\mathrm{Ti}_{2} \mathrm{Cu}$ and $\mathrm{Ti}_{2}(\mathrm{Cu}, \mathrm{Al})$ ) have their own growing speed towards the interface; which is a function of the brazing temperature, brazing duration and additive content, affect the overall joint strength directly ${ }^{18)}$. Jiang et. al. have found that the brazing of stainless steel (304 grade) to fins with nickel based filler, the strength is increased with brazing temperature. The microstructures in brazed joints are changed with brazing temperature and brittle phases are found to decline with the increase in brazing temperature ${ }^{19)}$. For aluminium based applications, low melting point braze fillers are generally used in the literature. For example, the popular Al-Si filler has been consistently researched and developed. In a re- cent study, Sharma et. al. incorporated $\mathrm{ZrO}_{2}$ nanoparticles in $\mathrm{Al}-\mathrm{Si}-\mathrm{Cu}$ filler to obtain improved joint properties as well as low melting point of the filler ${ }^{20}$.

\subsection{Interfacial/multilayers at the interface}

The formation of various interaction layers affects the brazed joint strength. It has been generally observed that interaction layers containing $\mathrm{CuTi}$ and $\mathrm{Cu}_{2} \mathrm{Ti}$ are formed in $\mathrm{Ti}-6 \mathrm{Al}-4 \mathrm{~V} / \mathrm{ZrO}_{2}$ using an $\mathrm{Ag}-\mathrm{Cu}-\mathrm{Sn}$-Ti filler ${ }^{12,21-22)}$. It has been already discussed that various multilayers or reaction products form at different temperatures. Generally, $\mathrm{Cu}_{2} \mathrm{Ti}$ forms at low brazing temperature and increases at high temperature, thus imparting highest hardness value ${ }^{23)}$. Therefore, a control of these reaction layers is important for achieving the best set of joint properties. A smaller thickness of these layers or IMCs corresponds to a higher brazed joint strength. An increase in the brazing temperature causes an increase in IMC thickness and vice versa ${ }^{24)}$.

\subsection{Wettability}

One of the very important criteria for any metal to be used as a filler in the brazing process is that it should wet and spread well over the contacting surfaces. Wetting can be defined as the ability of the molten filler metal to spread uniformly onto the surface of a metal after reflow procedure, and it should make a perfect bond with the base metal ${ }^{25)}$. Figure 2.3 shows examples of wetting and de-wetting phenomena ${ }^{25)}$.

Generally wetting depends on the wetting angle $(\theta)$ as shown in Figure 2. The wettability is an important factor in brazing applications. The contact surfaces to be joined should be wet enough to make a bond and avoid any faulty joining. The addition of $\mathrm{Sn}$, and $\mathrm{Ti}$ in $\mathrm{Al}-\mathrm{Si}$ alloy improves the brazeability by increasing the fluidity of the filler alloy ${ }^{26-27)}$. However, a high amount of Sn is not desirable as it may increase pitting and can be
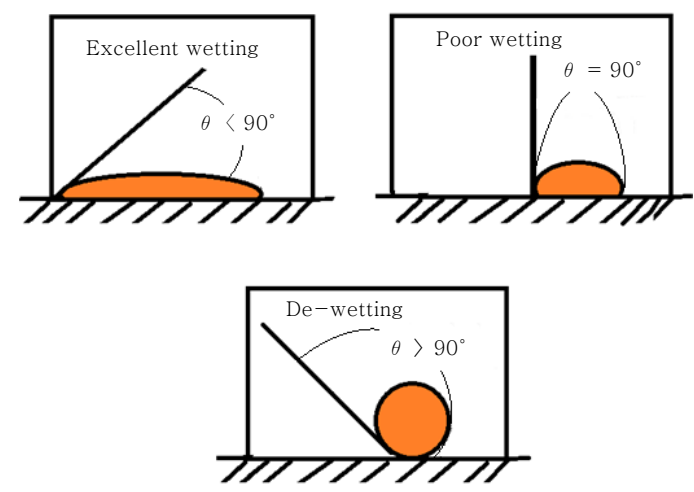

Fig. 2 Schematic diagram to show the wetting phenomena as a function of wetting angle 
deleterious for the joints ${ }^{26)}$. Magnesium is also an important element that is used to increase the wetting in some operations. It provides additional strengthening to the alloy and improves work-hardening rate in multiple brazing filler operations. Magnesium containing metal is assumed as candidate replacement for high strength alloys, or steel, primarily in view of the excellent elongation, toughness, as well as better working characteristics $^{28-30)}$.

The wetting properties provided by the magnesium are generally due to the reaction of $\mathrm{Mg}$ with oxygen or moisture impurities as given by the following equations ${ }^{31)}$.

$$
\begin{aligned}
& \mathrm{Mg}+\mathrm{H}_{2} \mathrm{O} \rightarrow \mathrm{MgO}+\mathrm{H}_{2} \\
& 2 \mathrm{Mg}+\mathrm{O}_{2} \rightarrow 2 \mathrm{MgO} \\
& \mathrm{Mg}+\mathrm{CO}_{2} \rightarrow \mathrm{MgO}+\mathrm{CO}
\end{aligned}
$$

In the case of ceramic-metal brazing, wettability is a crucial factor due to poor wetting properties of engineering ceramics. It has been observed that the poor wettability of ceramic can be improved by using alloys such as modifiers and wetting promoters ${ }^{32)}$. Various grain refiners such as, Ti, B, Sr, Na, Ca, P, Sb, Be, Ni, rare earth elements, oxides, etc. in brazing fillers are also added to increase the wetting and brazeability, and improve the quality of brazed joint and to produce minimum cracks and pores which may arise due to the non-uniform microstructures in Al-Si alloys ${ }^{33-39)}$.

\subsection{Manufacturing route}

Various changes in the processing routes or employing an additional/ sequential step may also reduce the cost and time. This can also affect the brazing microstructure as well as strength considerably. For example, the brazing of the extra pure $\mathrm{Ti} / \mathrm{Al}_{2} \mathrm{O}_{3}$ joint brazed by the introduction of titanium hydride, the need for additional steps like metallization, electrodeposition and heating steps to the desired brazing temperature may be eliminated $^{40}$.

\subsection{Atmosphere}

Brazing in a vacuum is relatively economical method to provide a controlled brazing environment. It is an excellent way of protecting the workpiece from oxidizing agents as well as foreign impurities. The vacuum level generally used for this type brazing falls in the range $\approx$ $10^{-3}$ to $10^{-5}$ mbar $^{40)}$. Other commonly used atmospheres are nitrogen, hydrogen, argon, etc. It has been reported that the brazing under controlled nitrogen atmosphere reduces the amount of flux required (NOCOLOK flux) ${ }^{41-42)}$. Reducing atmospheres too prevent the formation of surface oxides and reducing the metal oxides during brazing ${ }^{1)}$.

\subsection{Overlapped width}

It has been reported that the shear strength of brazed joints is highly dependent on the lap width to a greater extent. The brazed shear strength of the joints increases with the decrease in the lap width. Similar results are observed when the lap joint of a highly pure titanium plate to a low-carbon steel plate is obtained under a vacuum furnace using silver-based filler ${ }^{23)}$. It is suggested to employ a lap width up to a maximum of thrice of the thickness of the base metal for a superior brazed joint strength ${ }^{23,43)}$.

\subsection{Agitation}

The effect of mechanical vibration also affects the strength of the brazed joint and the joining process. It has been reported that with an increase in vibration frequency from 0 to $400 \mathrm{~Hz}$ (and amplitude of $20 \mu \mathrm{m}$ ), the shear strength increases appreciably during induction brazing ${ }^{44)}$.

\subsection{Brazing duration}

When the vacuum brazing of Ti-Al-based alloy to 40Cr steel using $\mathrm{Ag}-\mathrm{Cu}-\mathrm{Zn}$ filler is performed, it is observed that a change in brazing duration causes a change in brazing strength as well as a change in the joint microstructure and vice versa ${ }^{45)}$. The brazing duration combined with the brazing time also affects the joint properties to a greater extent ${ }^{18,45)}$.

\subsection{Effect of different filler materials.}

Many different varieties of filler alloys are available in brazing applications. Some of the brazing filler materials and their effects are tabulated below ${ }^{31)}$ :

\section{Summary of the effect of different brazing parameters}

Brazing is a technologically efficient process for the joining of the metal, nonmetals and ceramics to one another. Brazing has a wide promising future in automobiles, automotive, and aerospace industrial applications. More specialized methods are expected to emerge in future due to a vast development in the automotive and aerospace vehicles. Therefore, this paper throws a light on the effect of various parameters on the various brazing techniques and materials for a better understanding 
Table 1 Summary of the effect of additional elements in Al based brazing filler ${ }^{31)}$

\begin{tabular}{|c|c|c|}
\hline Alloy System & Additional element & Properties enhanced \\
\hline $\mathrm{Al}-\mathrm{Cu}, \mathrm{Al}-\mathrm{Zn}, \mathrm{Al}-\mathrm{Mg}$ etc. & $\mathrm{Si}$ & $\begin{array}{l}\text { Fluidity and brazeability improve. However, the formation of big } \mathrm{Si} \\
\text { needles is not desired due to crack generation problem. }\end{array}$ \\
\hline Al-Si, Al-Zn, etc. & $\mathrm{Cu}$ & $\begin{array}{l}\text { Improves age hardening mechanism, formation of GP zones, however } \\
\mathrm{CuAl}_{2} \text { is not good for a good brazing joint. }\end{array}$ \\
\hline $\mathrm{Al}-\mathrm{Si}, \mathrm{Al}-\mathrm{Cu}, \mathrm{Al}-\mathrm{Zn}$, etc. & $\mathrm{Mg}$ & $\begin{array}{l}\text { Work hardening, better corrosion resistance (less than } 1 \mathrm{wt} \% \mathrm{Mg} \text { is } \\
\text { desired in brazing) }\end{array}$ \\
\hline $\mathrm{Al}-\mathrm{Mg}, \mathrm{Al}-\mathrm{Cu}, \mathrm{Al}-\mathrm{Si}$, etc. & $\mathrm{Ti}$ & Increase in strength if added in minute quantities. \\
\hline Al-Cu-Al-Si, Al-Mg, etc. & $\mathrm{Ni}$ & Ni enhances the elevated temperature strength and hardness. \\
\hline $\mathrm{Al}-\mathrm{Cu}, \mathrm{Al}-\mathrm{Si}, \mathrm{Al}-\mathrm{Mg}$, etc. & $\mathrm{Sn}$ & Reduces friction, improves brazeability \\
\hline $\mathrm{Al}-\mathrm{Cu}, \mathrm{Al}-\mathrm{Si}$, etc. & $\mathrm{Ca}, \mathrm{NA}, \mathrm{Sr}, \mathrm{P}, \mathrm{S}, \mathrm{Sb}$ & $\begin{array}{l}\text { Improves the morphology of the needle type } \mathrm{Si} \text { and distributes the } \\
\mathrm{CuAl}_{2} \text { IMCs }\end{array}$ \\
\hline $\begin{array}{l}\mathrm{Al}-\mathrm{Cu}, \mathrm{Al}-\mathrm{Si}, \mathrm{Al}-\mathrm{Mg}, \\
\mathrm{Al}-\mathrm{Si}-\mathrm{Fe}, \text { etc. }\end{array}$ & $\mathrm{Mn}, \mathrm{Cr}$ & $\begin{array}{l}\text { Improves the corrosion resistance, morphology of iron complexes in } \\
\text { the presence of } \mathrm{Fe}\end{array}$ \\
\hline Al-Si, Al-Cu-Fe, Al-Mg-Fe, etc. & $\mathrm{Be}$ & Neutralizes the bad effects of Fe impurities and improves strength. \\
\hline $\mathrm{Al}-\mathrm{Cu}, \mathrm{Al}-\mathrm{Si}, \mathrm{Al}-\mathrm{Mg}$, etc. & $\mathrm{Zn}$ & $\begin{array}{l}\text { Depression of melting point, not desirable for heat exchangers due } \\
\text { early to a quick vaporization nature. }\end{array}$ \\
\hline $\mathrm{Al}-\mathrm{Si}, \mathrm{Al}-\mathrm{Mg}, \mathrm{Al}-\mathrm{Cu}$, etc. & $\begin{array}{l}\text { Rare earth } \\
\text { elements }\end{array}$ & Eutectic modification, refinement of microstructure \\
\hline $\mathrm{Al}-\mathrm{Si}, \mathrm{Al}-\mathrm{Cu}, \mathrm{Al}-\mathrm{Mg}$, etc. & $\begin{array}{l}\text { Ceramic } \\
\text { nano-oxides }\end{array}$ & $\begin{array}{l}\text { Refinement of microstructure, reduction of melting point, improvement } \\
\text { of strength. }\end{array}$ \\
\hline
\end{tabular}

of the overall technological aspects. There are following conclusions that can be drawn from the present review.

1. Temperature has a vital role in the brazing process. Increase in temperature improves the brazeability, however, it should not be too high to cause enough formation of IMCs that decreases the joint strength.

2. Brazing duration should be enough to cause a proper reaction between the joints otherwise the wetting will be poor.

3. Formation of interfacial layers is crucial for the brazing technology. Therefore, a strict control of IMCs is required via temperature or time optimization.

4. Agitation during the brazing process improves the shear strength of the joint by eliminating the impurities and cracks.

5. A proper lap width should be selected to exercise the maximum benefit of the brazed strength.

6. Manufacturing route also affects the brazing process. Brazing is different in vacuum and in inert atmospheres depending on the materials to be joined.

7. Wetting of the surfaces is also an important factor. The braze filler should have proper wetting, that is further dependent on the number of additional elements present in the filler. Therefore, a proper brazing filler with a proper amount of the additive is required.

\section{Acknowledgements}

This work was supported by the Energy Efficiency \& Resources Core Technology Program of the Korea
Institute of Energy Technology Evaluation and Planning (KETEP) granted financial resource from the Ministry of Trade, Industry \& Energy, Republic of Korea (No. 20142020104380).

\section{References}

1. M.M. Schwartz, Brazing, $2^{\text {nd }}$ ed., The Materials Information Society, ASM International, Ohio, USA, (2001)

2. Brazing Manual, American Welding Society, Committee on Brazing and Soldering, Reinhold Publishing Corporation, New York, USA, (1963)

3. D. Pritchard, Soldering, Brazing and Welding, Crowood Press, (2001)

4. Kelly Ferjutz and Joseph R. Davis, ASM Handbook: Volume 6: Welding, Brazing, and Soldering $10^{\text {th }}$ ed., ASM International, (1993)

5. R. L. O'Brien, Welding Handbook: Welding Processes, 2, Welding Handbook, $8^{\text {th }}$ ed., American Welding Society, (1991)

6. R. A. Woods and I. B. Robinson, Flow of Aluminum Dip Brazing Filler Metals, Weld. J. Res. Suppl, 440s445s, (1974)

7. B. Daly, Basics of Brazing With Induction Heating, Weld. J., 52-54, (2013)

8. H. Riedelsberger, Laser Brazing in The Automotive Industry, AWS Welding Show Atlanta, (2006)

9. D. Steinmeir, Resistance Brazing Basics, Microjoining solutions, Arcadia, CA, (2003)

10. Introduction to Furnace Brazing, Air Products, Air Products and Chemicals, Inc. (2001)

11. The Brazing Guide by Induction Atmospheres, Industrial Park Circle, Rochester NY, (2009). (http://www.inductio-natmospheres. com/pdf/ BrazingGuide.pdf) 
12. S.-H. Kee, S.-Y. Park, Y.-Ku Heo, J.-P. Jung and W.-J. Kim, Brazing Characteristics of $\mathrm{ZrO}_{2}$ and Ti-6Al-4V Brazed Joints With Increasing Temperature, J. Kor.Acad. Prosthodont., 50 (2012), 169-175 (in Korean)

13. J. X. Zhang, R. S. Chandel and H. P. Seow, PTLP Joining of $\mathrm{Al}_{2} \mathrm{O}_{3}$-Stainless Steel 304 Using Ni-Cr Foil-The Microstructure Morphologies of Joint Interfaces, Mater. Manuf. Proc., 18(2) (2003), 181-193

14. M. Singh, T. Ohji and R. Asthana, Ceramic Integration and Joining Technologies: From Macro to Nanoscale, American Ceramic Society, John Wiley and Sons, New Jersey, (2011)

15. M. Singh, T.P. Shpargel, G.N. Morscher and R. Asthana, Active Metal Brazing and Characterization of Brazed Joints in Titanium to Carbon-Carbon Composites, Mat. Sci. Eng. A, 412 (1-2) (2005), 123-128

16. J.-H. Kim and Y.-C. Yoo, Bonding of Alumina To Metals With Ag-Cu-Zr Brazing Alloy, J. Mat. Sci. Lett., 16 (1997), 1212-1215

17. Y. M. He, J. Zhang, X. Wang and Y. Sun, Effect of Brazing Temperature on Microstructure and Mechanical Properties of $\mathrm{Si}_{3} \mathrm{~N}_{4} / \mathrm{Si}_{3} \mathrm{~N}_{4}$ joints brazed with $\mathrm{Ag}-\mathrm{Cu}-\mathrm{Ti}+\mathrm{Mo}$ Composite Filler, J. Mater. Sci. 46 (2011), 2796-2804

18. M.Yang, P. He and T. Lin, Effect of Brazing Conditions on Microstructure and Mechanical Properties of $\mathrm{Al}_{2} \mathrm{O}_{3} /$ Ti-6Al-4V Alloy Joints Reinforced by TiB Whiskers, J. Mater. Sci. Technol., 29 (2013), 961-970

19. W. Jiang, J. Gong and S.T. Tu, Effect of Brazing Temperature on Tensile Strength and Microstructure For A Stainless Steel Plate-Fin Structure, Mater. Des. 32 (2011), 736742

20. A. Sharma, M.H. Roh, D.H. Jung and J.P. Jung, Effect of $\mathrm{ZrO}_{2}$ Nanoparticles on The Microstructure of Al-Si$\mathrm{Cu}$ Filler For Low-temperature Al Brazing Applications, Metall. Mater. Trans. A, 47 (2016), 510- 521

21. S.H. Kee, Z. Xu, J.P. Jung and W.J. Kim, Joining of Ceramic and Metal Using Active Metal Brazing, J. Microelectron. Packag. Soc., 18(3) (2011), 1-7 (in Korean)

22. Y. Liu, J. Hu, Y. Zhang, Z. Guo and Y. Yang, Joining of Zirconia and Ti-6Al-4V Using A Ti-Based Amorphous Filler, J. Mater. Sci. Technol., 27 (2011), 653-658

23. A. Elrefaey and W. Tillmann, Interface Characteristics and Mechanical Properties of The Vacuum-Brazed Joint of Titanium-Steel Having A Silver-Based Brazing Alloy, Metall. Mater. Trans. A, 38 (2007), 956-2962

24. H.-J. Kim, J. Y. Lee, K.-W. Paik, K.-W. Koh, J. Won, S. Choe, J. Lee, J.-T. Moon and Y.-J. Park, Effects of $\mathrm{Cu} / \mathrm{Al}$ Intermetallic Compound (IMC) on Copper Wire and Aluminum Pad Bondability, IEEE Trans. Comp. Packag. Manuf., 26 (2003), 367-374

25. S. Kogi, T. Kajiura, Y. Hanada and Y. Miyazawa, Wetting and Spreading Behavior of Molten Brazing Filler Metallic Alloys on Metallic Substrate, IOP Conf. Series: Mater. Sci. Eng., 61 (2014), 012017

26. J. Li, Y. Liu, Y. Tan, Y. Li, L. Zhang, S. Wu and P. Jia, Effect of Tin Addition on Primary Silicon Recovery in
Si-Al Melt During Solidification Refining of Silicon, $J$. Cryst. Growth, 371 (2013), 1-6

27. S. Zor, M. Zeren, H. Özkazan, and E. Karakulak, Effect of Titanium Addition on Corrosion Properties of Al-Si Eutectic Alloys, Prot. Met. Phys. Chem. Surf., 48, (2012), 568-571

28. J. Aucote and D.W. Evans, Effects of Excess Silicon Addition on Ductility of Al- $0.95 \% \mathrm{Mg}_{2} \mathrm{Si}$ Alloy, Mat. Sci. Technol., 12 (1978), 57-63.

29. A.K. Dahle, K. Nogita, S.D. McDonald, C. Dinnis and L. Lu, Eutectic Modification and Microstructure Development in Al-Si Alloys, Mat. Sci. Eng. A, 413-414 (2005), 243-248

30. I.J. Polmear, Light alloys From Traditional Alloys to Nanocrystals, $4^{\text {th }}$ ed., Elsevier-Butterworth Heinemann, (2006)

31. A. Sharma, Y.S. Shin and J.P. Jung, Influence of Various Additional Elements in Al Based Filler Alloys For Automotive and Brazing Industry, J. Welding and Joining, 33(5) (2015), 23-30 ( in Korean)

32. I. Calliari, E. Ramous, K. Brunelli and P. Favaron, Characterization of Vacuum Brazed Joints for Super- conducting Cavities, Microchim. Acta, 147(3) (2004), 141-146

33. T. N. Ware, A. K. Dahle, S. Charles and M. J. Couper, Effect of $\mathrm{Sr}, \mathrm{Na}, \mathrm{Ca} \& \mathrm{P}$ on the Castability of Foundry Alloy A356.2, ASM Materials Solutions, 2002 Conference \& Exposition, 2nd International Aluminium Casting Technology Symposium, Columbus, Ohio, USA, October 2002, 1-10

34. Y. Wang and Y. Xiong, Effects of Beryllium in Al-SiMg-Ti Cast Alloy, Mat. Sci. Eng. A, 280 (2000), 124127

35. M. Jaradeh and T. Carlberg, Effect of Titanium Additions on the Microstructure of DC-Cast Aluminium Alloys, Mat. Sci. Eng. A, 413-414 (2005), 277-282

36. M. O. Krasovskii1 and V. O. Lavrenko: Effect of Antimony and Bismuth on the Electrochemical Corrosion of the Cast Aluminium Silicon Alloys in 3\% $\mathrm{NaCl}$ Solution, Powder Metall. Met. Ceram., 49 (2011), 716-721

37. F. Stadler, H. Antrekowitschn, W. Fragner, H. Kaufmann, E.R. Pinatel and P.J. Uggowitzer, The Effect of Main Alloying Elements on the Physical Properties of Al-Si Foundry Alloys, Mat. Sci. Eng. A 560 (2013), 481-491

38. D.H. Xiao, J.N. Wang, D.Y. Ding and H.L. Yang, Effect of Rare Earth Ce Addition on the Microstructure and Mechanical Properties of an Al-Cu-Mg-Ag Alloy, $J$. Alloy. Compd., 352 (2003), 84-88

39. Tao Lu, Ye Pan, Ji-li Wu, Shi-wen Tao and Yu Chen, Effects of La Addition on the Microstructure and Tensile Properties of $\mathrm{Al}-\mathrm{Si}-\mathrm{Cu}-\mathrm{Mg}$ Casting Alloys, Int. J. Min. Met. Mater., 22 (4), (2015), 405-410

40. O. C. Paiva and M. A. Barbosa, Production, Bonding Strength and Electrochemical Behavior of Commercially Pure Ti $/ \mathrm{Al}_{2} \mathrm{O}_{3}$ Brazed Joints, J. Mat. Sci., 32 (1997), 653-659

41. R. S. Timsit and B. J. Janeway, A Novel Brazing Technique 
For Aluminum, Weld. J. Res. Suppl., 119s-128s, (1994)

42. R. Andersson, T. Holm, S. Wiberg and A. Astrom, Furnace Atmospheres No. 4, Brazing of Metals, Special Edition, Linde Gas, Germany, 1-43

43. E. Ganjeha, H. Sarkhoshb, M.E. Bajgholic, H. Khorsanda and M.H. Ghaffarid, Increasing Ti-6Al-4V Brazed Joint Strength Equal to the Base Metal by $\mathrm{Ti}$ and $\mathrm{Zr}$ Amorphous Filler Alloys, Mater. Charact., 71 (2012), $31-40$
44. X. Wu, H. Li, R. S. Chandel and H. P. Seow, Effect of Mechanical Vibration on TLP Brazing With BNi-2 Nickel-Based Filler Metal, J. Mater. Sci. Lett., 18 (1999), 1615-1617

45. L. Huijie and F. Jicai, Vacuum Brazing TiAl-Based Alloy to $40 \mathrm{Cr}$ Steel Using Ag-Cu-Zn Filler Metal, $J$. Mater. Sci. Lett., 21 (2002) 9-10 